\title{
黄疸障害肝における組織ポリアミンの動態
}

ーラット胆管閉塞および閉塞解除後の肝切除再生肝の検討一

名古屋大学第 1 外科（主任：塩野谷恵彦教授）

\author{
浅 井 雅 則
}

\section{THE DYNAMICS OF POLYAMINES IN REGENERATING RAT LIVER \\ AFTER BILIARY OBSTRUCTION AND RELEASING THE OBSTRUCTION}

\section{Masanori ASAI}

The First Department of Surgery, Nagoya University School of Medicine

(Director : Prof. Shigehiko Shionoya)

ラットを用い, 黄疸群, 黄疸軽減群 (以下減黄群), 正常肝切除群, 黄疸肝切除群, 減黄肝切除群を 作製し，組織ポリアミンと血清 GOT，GPT の動態を比較検討した，黄疸群の組織プトレシン（以下 Put), スペルミシシン (以下 Spd) は正常肝切除群と同様の経時的変化を示した. 両群の組織 Put の変 化は血清 GOT，GPT とよく相応していた，黄㾝肝切除群のごとき肝障害が重篤になると血清 GOT， GPT は障害に比例して増加しなかったが，組織 Put は正常肝切除群に比べ著明な増加と高値の持続 を示した. 減黄肝切除群の組織 Put は正常肝切除群のそれに近づい。. 組織 Put の動態は, 再生より 障害の程度と比例したことより障害の指標になると考えられた。また障害に対する代償的保護因子の 働きを持つと考えられた。

案引用語：肝障害とポリフミン, 肝障害とプトレシン, 肝再生, 閉塞性黄疾, 減黄

\section{I. 緒 言}

閉塞性黄疸の患者の手術は極めて成績が不良であっ た，近年胆道癌などに，経皮経肝胆道ドレナージ（以 下 $\mathrm{PTC}\left(\mathrm{D}^{1) \sim 3)}\right)$ により黄疸軽減した後に, 腫場部分を含 めた広範囲肝切除が比較的安全に施行されるよ5に なってきた。

正常肝部分切除後の残存肝の肝再生に関する研究は 古くより基礎, 臨床の両面から多くの研究がなされて きた。しかし臨床的にしぱしば遭遇する黄疸肝障害下 での肝切除および减黄後の肝切除再生肝に関する基礎 的な研究はほとんど行われていない。

ラット肝部分切除後の再生肝でポリアミンとくに Put, Spd が早期より増加することが報告されてきた。 なた種々の肝毒性をるつ薬物による障害肝でも組織 Put が著明に増加することが報告されてきた。

$<1985$ 年 7 月 10 日受理 $>$ 別刷請求先：浅井 雅則 于466 名古屋市昭和区鶴舞町65 名古屋大学医学部 第 1 外科
今回再生拉よび障害で増加する Put に着目し，黄疸 障害肝での肝切除, 黄疸軽減後の肝切除々いら臨床に 即した実験モデルをラットにて作製し, 各状態での組 織ポリアミンを比較検討した。.とくに, 組織 Put の障 害肝および再生肝での役割, 意義につき検討した。

\section{II. 実験材料および方法}

1. 実験動物およびその管理

生後 3 4 力月齢, 体重300 400g の雄性吞竜ラッ 卜（中島実験動物より購入）を用いた。オリエンタル 製固型飼料を水と共に自由に撕取させた。 シットは各 群 $\mathrm{n}=5 \sim 6$ とし, 実験に供する前 1 力月間空調室で 飼育した。

2. 実験方法

以下の各群に分けて検索した。

(1) 黄疾群

ラットを無麻酔下に正中線切開開腹後, 左主羘管が 肝外胆管に合流する部より肝側の肝外胆管に外径1 $\mathrm{mm}$ 内径 $0.5 \mathrm{~mm}$ (八光電機製作所製) のビニール管を 
插入固定し, 他端は結禁し, 皮下を通して頭頂部やや 左耳よりの皮下に固定し, 胆管閉塞黄㾝群を作製した。 胆管閉塞後各 12 時間， $1,2 ， 3$ 日，1，2，3，4週間に 断頭屠殺して，採血採肝を行った。

(2) 減黄群

胆管閉塞 1 週間後に, 頭頂部皮下のビニール管の結 禁を解放し外胆汁瘦とし減黄した。减黄 $6,24,72$ 時間 後断頭屠殺して採血採訮を行った。

(3) 肝切除群

(i) 正常肝切除群

ラットを無麻酔下に正中線切開開復し, Higgins \& Anderson 法 ${ }^{4}$ に従って左葉扣よび中葉を出来るだけ 根部で結禁し約 $68 \%$ の肝を切除した。肝切除は午前 9 時から11時の間に行った。肝切除後各 $4,8,12,16$, 20 ，24時間， $2 ， 3 ， 4 ， 7,10 ， 14$ 日に断頭屠殺して採 血採肝を行った。

(ii) 黄宣肝切除群

胆管閉塞 1 週間後, 無麻酔下に前回と同じ手術創を 切開開腹し，68\%訮切除を行った。

(iii) 减黄肝切除群

减黄 6,24,72時間の各群に，同様に68\%肝切除を 行った.（ii）(iii)の両群は, 肝切除後各 $4,8,12,16$, 20，24時間後断頭屠殺し，採血採肝を行った。

(4) 胆计採取群

黄疾群と同様にビニール管を捜入固定し，他端にビ ニール袋を装着した。袋を腹腔内に留置後, $68 \%$ 肝切 除を施行した，代謝ケージに移し，12時間蓄尿後断頭 屠殺し採血した。胆汁は開腹し，ビニール袋より採取 した，対照群は，肝切除を加えず腹腔内にビニール袋 を留置し，12時間後断頭屠殺し採血採尿および胆汁を 採取した。

\section{3. 検索項目}

(1) 再生率の測定

再生率は Fishback ${ }^{5}$ による計算式すなわち残存肝 重量を Higgins \& Anderson ${ }^{4}$ による推定全肝重量で 除した値（\%）を用いた。

（2）血液生化学検查

血清総ビリルビンは Michaëlson ${ }^{6}$ 変法による, アル カリアゾビリルビンブルー比色定量法にて測定した。 血清 Glutamic oxaloacetic transaminase（以下 GOT), Glutamic pyruvic transaminase (以下 GPT) はWróblewski-Karmen ${ }^{7)}$ 法に準じ，日立706D 自動分 析装置を用いて測定した.

（3）肝組織 DNA, RNA 量の測定
Schmidt-Thannhauser ${ }^{8)}$ 法に準じて，ラット肝組織 より核酸を抽出した. DNAの定量は, ジフェニルアミ ン9)法により，RNAの定量はオルシノール法9)により 測定した。

（4）組織ポリアミンの測定

断頭屠殺後直ちに訮を摘出し, 生理食塩水で十分洗 淮し，血液成分を出来るた゚け除去した。肝重量測定後, 肝湿重量1gに精製水を加光，氷冷下にPotter ホモゲ ナイザーにて，10\%(W/V) のホモジネート液を作製 した。ホモジート液 $2 \mathrm{ml}$ (肝湿重量 $200 \mathrm{mg}$ 相当)に $10 \%$ 過塩素酸 (以下 PCA) $3 \mathrm{ml}$ を加学 $3,500 \mathrm{rpm} 15$ 分 間遠沈して除蛋白を行った。沈潵物にさらに $10 \% \mathrm{PCA}$ $3 \mathrm{ml}$ で 1 回, $5 \% \mathrm{PCA} 3 \mathrm{ml}$ で 1 回の計 3 回同様の操作 を行い，その上清を集め酸可溶性分画とした，前処理 として上清に $\mathrm{NaOH}$ を加え $\mathrm{pH}$ 6.5に調整し, 松本 ら ${ }^{10) 11}$ の方法に準じて陽イオン交換樹脂 Amberlite CG 50 (オルガノ社製, タイプ 1)を用いたミニカラム で夾雑物質を除去した，ポリアミンの分離定量には島 津高速液体クロマトグラフ LC 5A で藤田ら ${ }^{12)}$ の方法 に準じてイオン交換樹脂 CK-10U（三菱化成社製）を 充填した分離カラムを用いたポストカラム法にて行っ た. 分析所要時間は約 20 分であり, $2 \mathrm{pmol}$ より $200 \mathrm{pmol}$ まで良好な検量線が得られた。肝ホモジネート液にプ トレシン (Put)-2HCL, カダベリン (以下 Cad)-2HCL, スペルミジン (Spd)-3HCL, スペルミン (以下 Spm). $4 \mathrm{HCL}$ (半井社製)を各 $200 \mathrm{nmol}$ 添加し, 前記の方法で 測定したところ，おのおの95\%，90\%，96\%，98\%と 良好な回収率を得た（表 1 ）.

（5）胆汁，血清，尿中ポリアミンの測定

胆汁採取群より得られた胆汁，血清各 $2 \mathrm{ml}$ に $10 \%$ PCA $2 \mathrm{ml}$ 㧊よび5\% PCA $2 \mathrm{ml}$ で 2 回除蛋白処理した。 その上清に濃塩酸 $1 \mathrm{ml}$ を加え, $110^{\circ} \mathrm{C}$ で 6 時間加水分解 した，尿は尿量計測後尿 $2 \mathrm{ml}$ に濃塩酸を $1 \mathrm{ml}$ 加え同様 に加水分解した. 加水分解後, 上清に $\mathrm{NaOH}$ を加え, pH 6.5に調整し, 松本ら ${ }^{10) 11)}$, の方法に準じ Amberlite CG 50を用いたマイクロカラムで夾雑物質を除去後, 組織と同様に高速液体クロマトグラフで分離定量し た。胆汁, 血清, 尿における Put, Spd, Spm の回収率 はいずれる $90 \%$ 以上の良好な結果を得た。

\section{III. 成}

（1）黄疾群

(i) 血清総ビリルビン値の変化

胆管閉塞 12 時間後に $5.0 \pm 0.9 \mathrm{mg} / \mathrm{dl}$ と高値を示し, 1 週間後 $9.3 \pm 1.3 \mathrm{mg} / \mathrm{dl}$ とピーク値を示した。胆管閉 
表 1 測定条件

装置：島津高速液体クロマトグラフ LC-5A

カラム $\mathrm{CK} \cdot 10 \mathrm{U}$

移動 相：0.2N クエン酸ナトリウム

$2.5 \mathrm{~N}$ 塩化ナトリウム

反芯試薬 : 0 -フタルアルデヒド

2-メルカプトエタノール

検出器: 島津蛍光計 FLD-2A

1) Standard

Put $40 \mathrm{pmol}$

Cad $40 \mathrm{pmol}$

Spd $40 \mathrm{pmol}$

Spm 80 pmol

2) 正常肝切除後 12時間
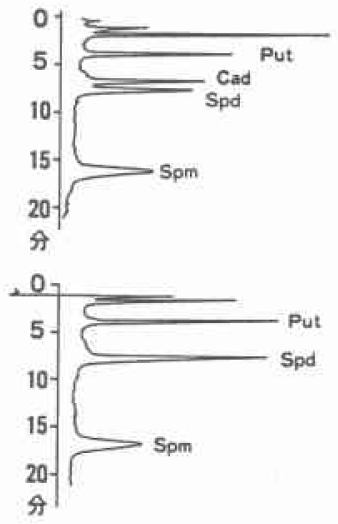

塞期間が長くなっても増加せず，むしろ減少する傾向 がみられた（図1）。

(ii) 血清 GOT, GPT の変化

GOT は胆管閉塞12時間後に一過性に1,678土633U と著明なピーク値を示した。 その後 1 週間目までは減 少するがその後再び 3 週目まで漸増した.GPT す 12 時 間後768土 $150 \mathrm{U}$ とピーク値を示し, GOT と同様の変 化を示した（図2）.

図 1 黄疸群の血清総ビリルビン值

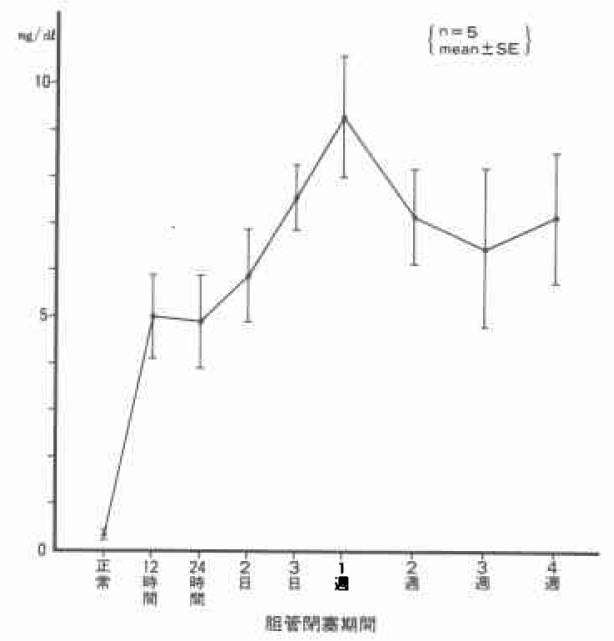

図 2 黄㾝群の血清 GOT, GPT

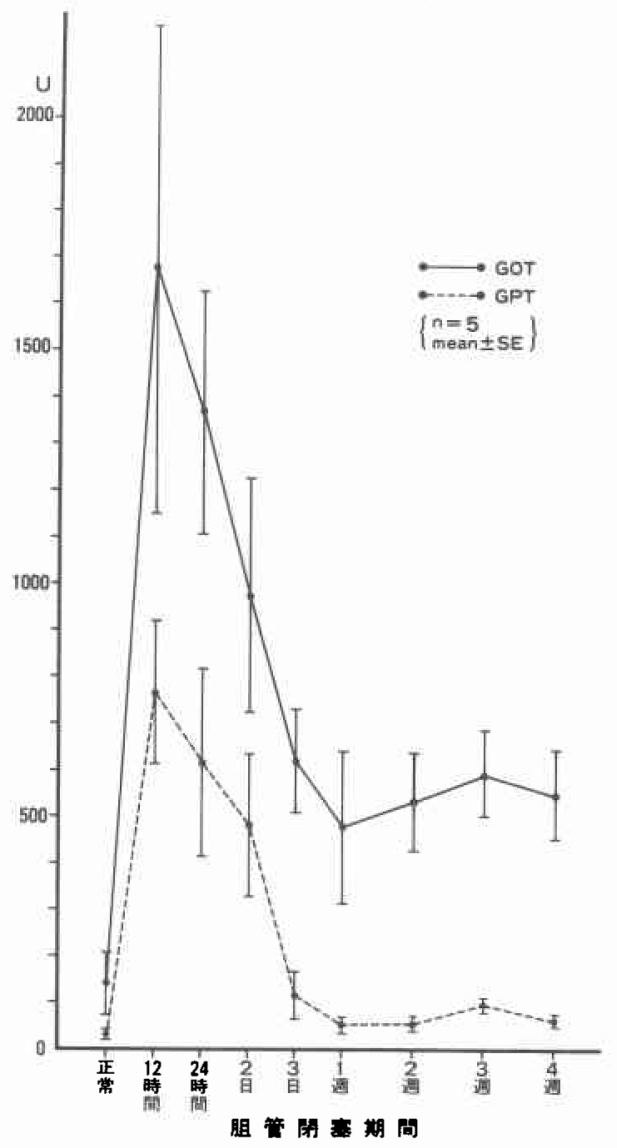

(iii) 組織ポリアミンの変化

Put は胆管閉塞12時間後に一過性に478土47nmol $/ \mathrm{g}$ 湿重量と正常の約50倍のピーク値を示すが，24時間後 には $90 \pm 10 \mathrm{nmol} / \mathrm{g}$ 湿重量と减少した。しかし 4 週間 後も56士 $8 \mathrm{nmol} / \mathrm{g}$ 湿重量と正常の 5 倍の高值を持続 した. Spd は12時間後减少するが，その後著明な増加 を示し， 3 日後には $1,339 \pm 90 \mathrm{nmol} / \mathrm{g}$ 湿重量とピーク を示し，その後漸減した. Spmは2 日まで漸減し，そ の後増加し, 1 週間後に $986 \pm 15 \mathrm{nmol} / \mathrm{g}$ 湿重量とピー ク値を示した（図 3).

(2) 减黄群

(i) 血清総ビリルビン値の変化

1 週間胆管閉塞後減黄した. 減黄 6 時間で $2.7 \pm 0.4$ $\mathrm{mg} / \mathrm{dl}$ と著明に減少した。减黄72時間で0.6土0.2mg/ dl とほぼ正常値に復した（図4).

(ii) 血清 GOT, GPT の変化

GOT は 1 週間胆管閉塞で, $476 \pm 168 \mathrm{U}$ と増加する 
困 3 黄㾝群の組織ポリアミン

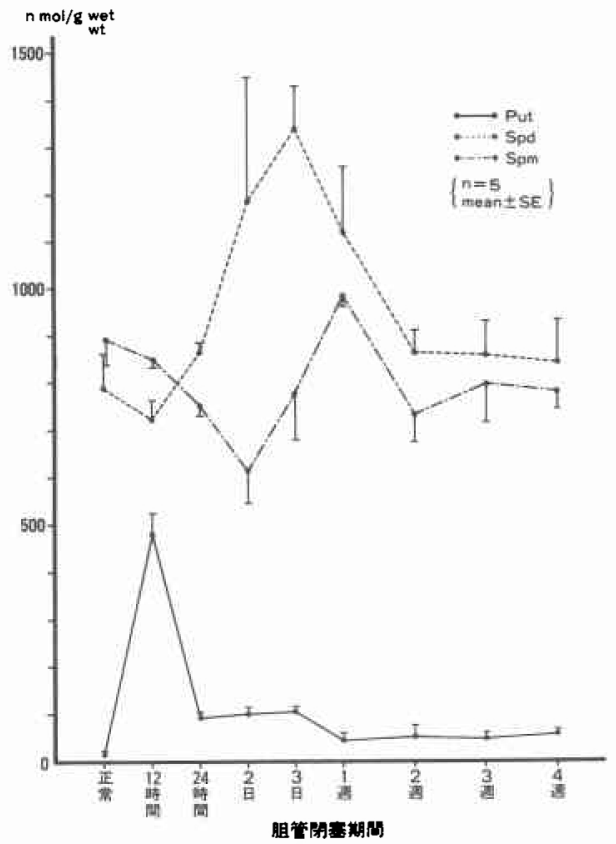

図 4 减黄群の血清総ビリルビン値

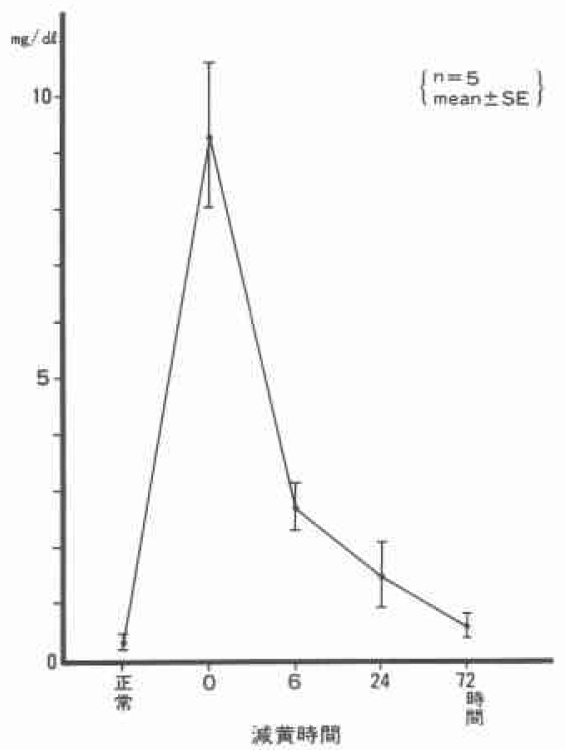

が減黄時間とともに著明に減少した.GPTは 1 週間胆 管閉塞により $48 \pm 13 U$ と増加し, 减黄により減少した (図 5 ).

(iii) 組織ポリアミンの変化

Put, Spd ともに減黄期間に比例して減少し, 减黄72
図 5 减黄群の血清 GOT, GPT

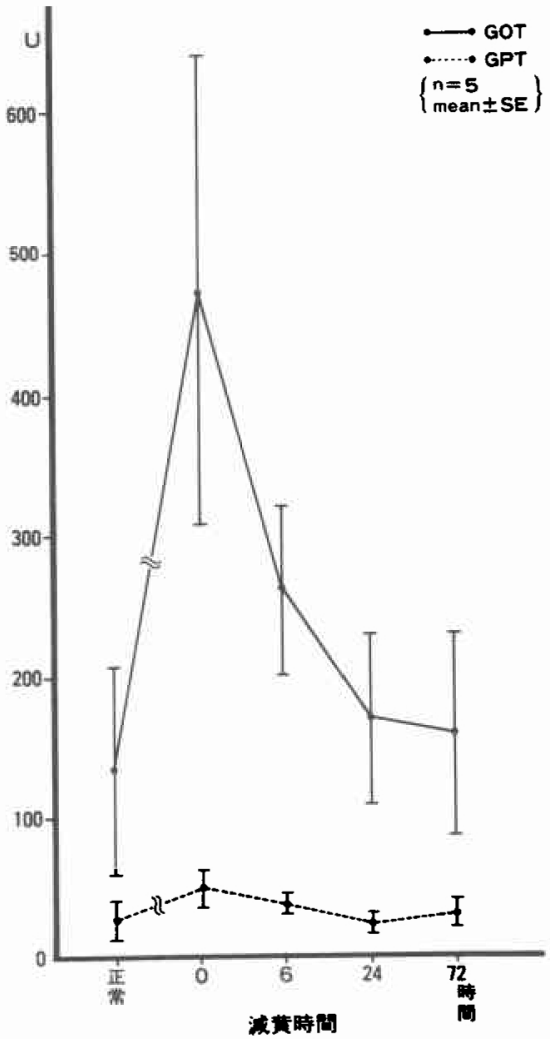

時間後には正常値に復した（図 6).

(3) 正常肝切除群

(i) 肝再生率の変化

肝切除後24時間より漸増し，14日後にはもとの重量 のほぼ90\%に復した（図 7）

（ii）血清 GOT, GPT の変化

GOT は肝切除後急激に増加し，12時間後には， 2,019土507U とピーク值を示した. 以後減少し14日後 には170土47U とほぼ正常値に回復した. GPT b12時

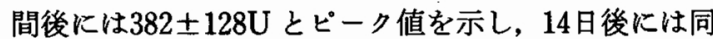
様にほぼ正常値に回復した（図8）

(iii) 組織 DNA, RNA 量の変化

DNA 量は肝切除後24時間までは漸减し，その後増 加し，4 日後には $2.00 \pm 0.23 \mathrm{mg} / \mathrm{g}$ 湿重量となり，それ 以後やや减少する傾向がみられた。 RNA 量は, 肝切除 前 $5.90 \pm 1.22 \mathrm{mg} / \mathrm{g}$ 湿重量であり肝切除後 24 時間まで は大きな変動はないが 3 日後には急速に増加し9.76士 $0.67 \mathrm{mg} / \mathrm{g}$ 湿重量とピーク値を示した。以後减少し 14 日後にはほぼ正常値に復した（図9） 
因 6 隇黄群の組織ポリアミン

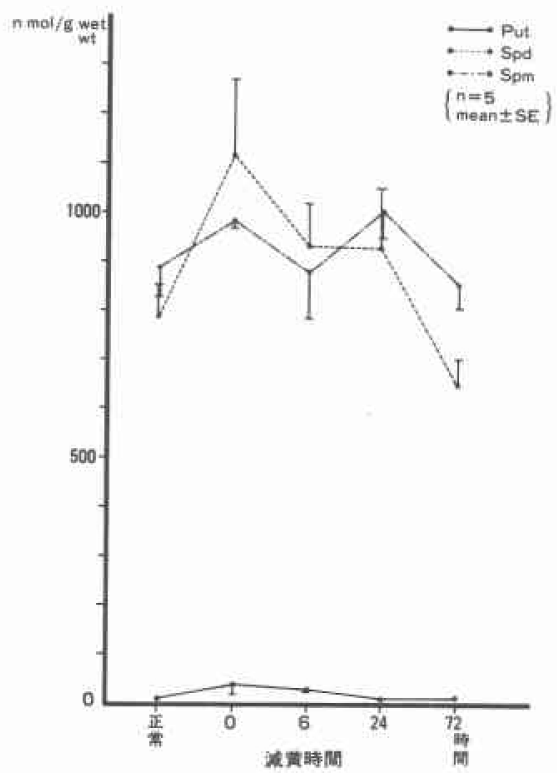

図 7 正常肝切除群の肝再生率の変化

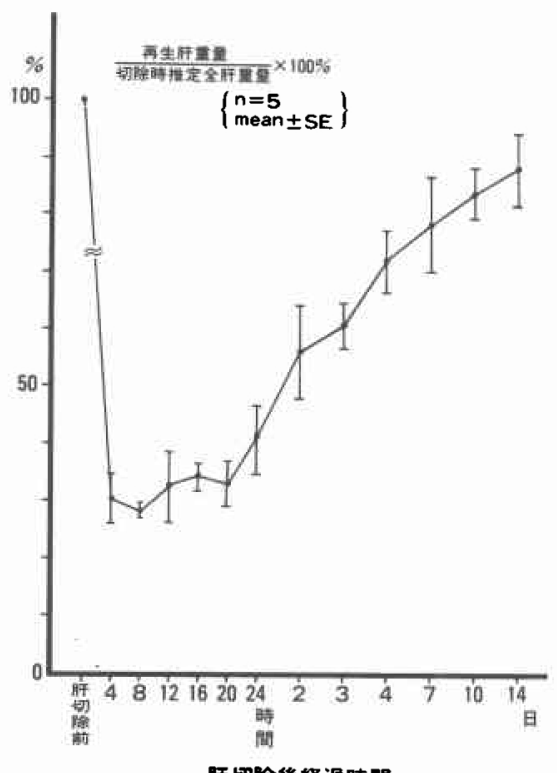

周切除後経過時間

(iv) 組織ポリアミンの変化

肝切除前の組織 Put は $10 \pm 7 \mathrm{nmol} / \mathrm{g}$ 湿重量と極め て低値であるが肝切除後 4 時間より急速に增加し12時 間後には $564 \pm 136 \mathrm{nmol} / \mathrm{g}$ 湿重量とピーク值を示し た.これは肝切除前の50倍以上であった。 以後急速に 減少し24時間後には, $60 \pm 21 \mathrm{nmol} / \mathrm{g}$ 湿重量となり 14
因 8 正常肝切除群の血清 GOT, GPT

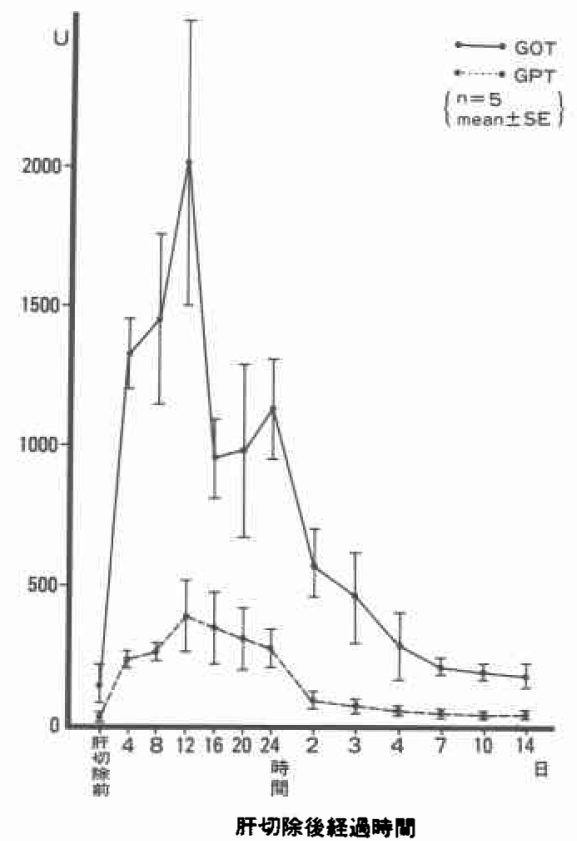

図 9 正常肝切除群の DNA, RNA 量の变化

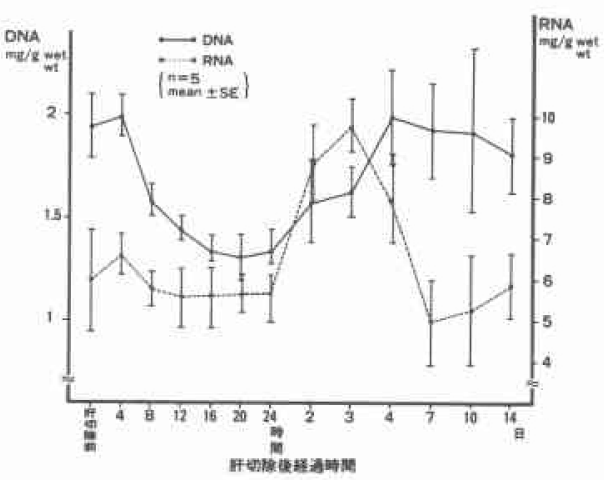

日後には, ほぼ正常值に復した. Spd は肝切除前790士 $66 \mathrm{nmol} / \mathrm{g}$ 湿重量で肝切除後12時間までは減少するが 以後急速に増加し, 3 日後には $1,817 \pm 349 \mathrm{nmol} / \mathrm{g}$ 湿 重量と切除前の約 2.3 倍に増加した. 3 日後は漸减し 14 日後には正常値に復した. Spm は肝切除前 $892 \pm 57$ $\mathrm{nmol} / \mathrm{g}$ 湿重量で肝切除後一定の傾向を示さなかった (図10)

（4）黄疸肝切除群，减黄肝切除群および正常肝切除 群の比較検討

（i）各肝切除群の血清総ビリルビン値の変化 減黄期間が長い群ほど, 肝切除後の血清総ビリルビ 
図10 正常肝切除群の組織ポリアミン

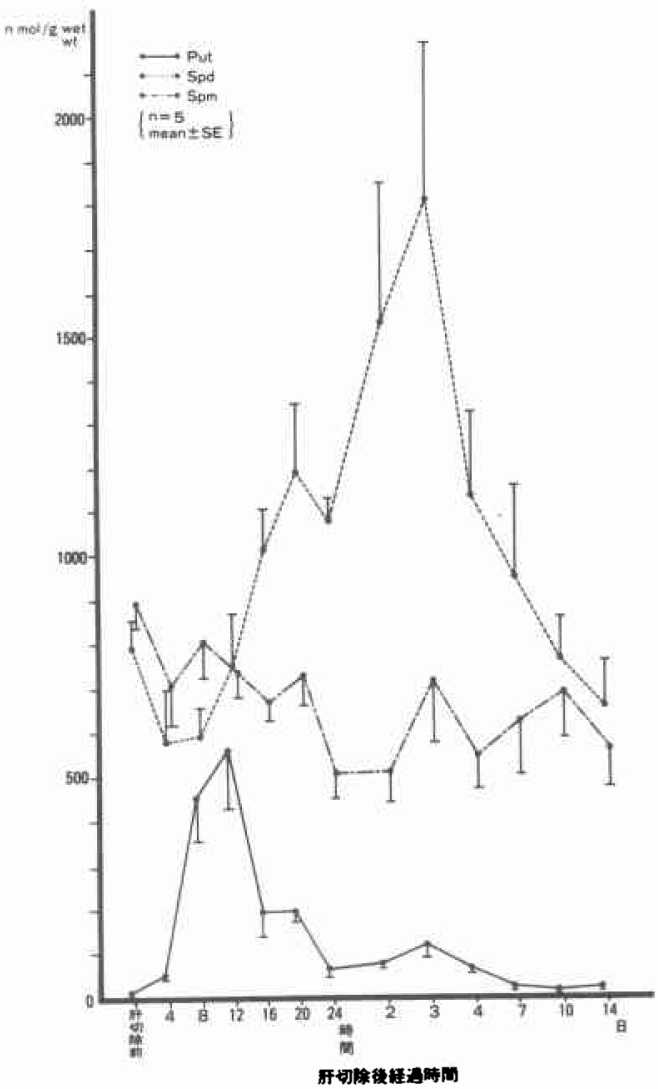

ン値多低かった（図11）.

（ii）各肝切除群の血清 GOT, GPT の変化

正常肝切除群, 減黄肝切除群の血清 GOT は肝切除 12時間後にすべてピーク值を示した．正常肝切除群が もっともピーク值が高く，減黄時間が長く肝機能が回 復した群ほどピークが高值となる傾向がみられた（図 12). 黄疸肝切除群の血清 GOT は正常肝切除群に比べ 肝切除12時間後の値は有意に低かった（図13）。各肝切 除群の血清 GPT の変化は血清 GOT と同様の変化を 示した。

(iii）黄㾝肝切除群の組織ポリアミンの変化

Put は肝切除 4 時間以後急速に增加し，12時間後に は852士 $197 \mathrm{nmol} / \mathrm{g}$ 湿重量とピーク値を示した. 24時 間後子676士192nmol $/ \mathrm{g}$ 湿重量と高値を持続遷延し た. Spdは肝切除により急速に減少し，12時間後620士 $121 \mathrm{nmol} / \mathrm{g}$ 湿重量と最低值を示したが以後急速に増 加した. Spm は一定の傾向を示さなかった（図14）.

(iv) 減黄 6 時間肝切除群の組織ポリアミンの変化
図11各肝切除群の血清総ビリルビン値

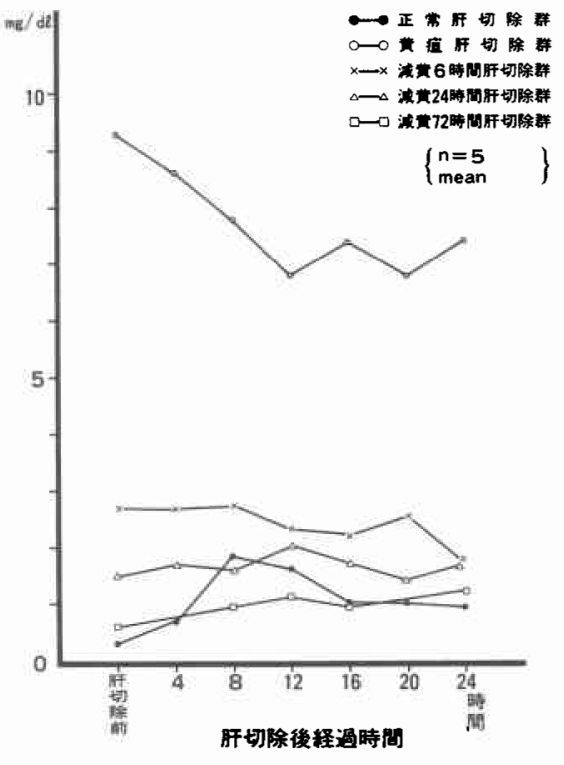

図12 各肝切除群の血清 GOT

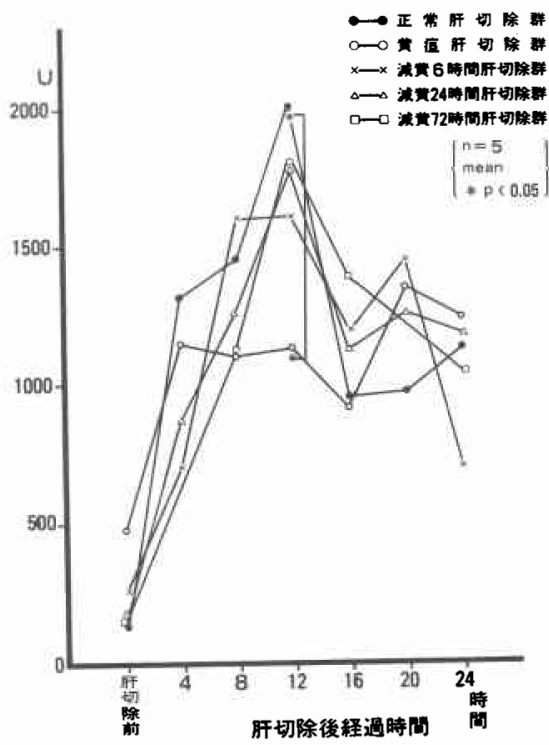

Putは肝切除12時間後 $826 \pm 139 \mathrm{nmol} / \mathrm{g}$ 湿重量と ピーク值を示し，その後减少し24時間後には $273 \pm 92$ $\mathrm{nmol} / \mathrm{g}$ 湿重量となった。 Spd は12時間までは徐々に 減少し，以後急速に増加する傾向がみられた。 Spmは 24時間までわずかに減少する傾向がみられた（図15）.

(v) 减黄24時間肝切除群の組織ポリアミンの変化

Put は肝切除12時間後に660 $184 \mathrm{nmol} / \mathrm{g}$ 湿重量と ピークを示し，以後減少し24時間後には $248 \pm 48$ 
図13 各肝切除群の血清 GPT

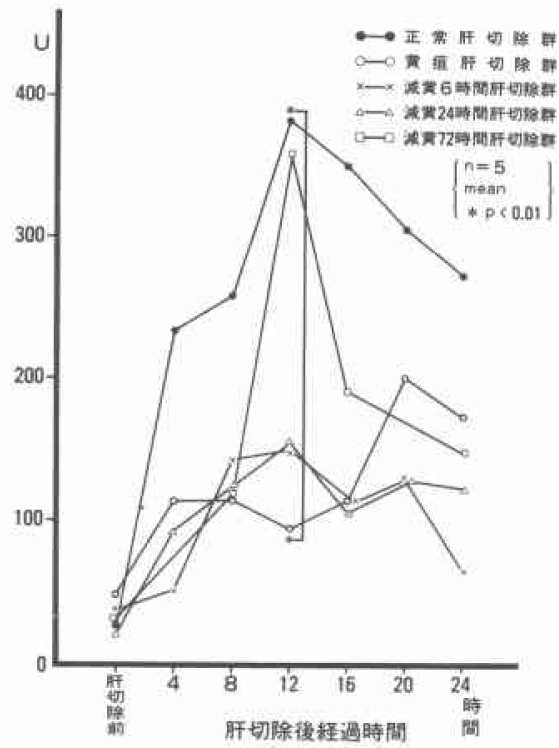

図14 黄疸肝切除群の組織ポリアミン

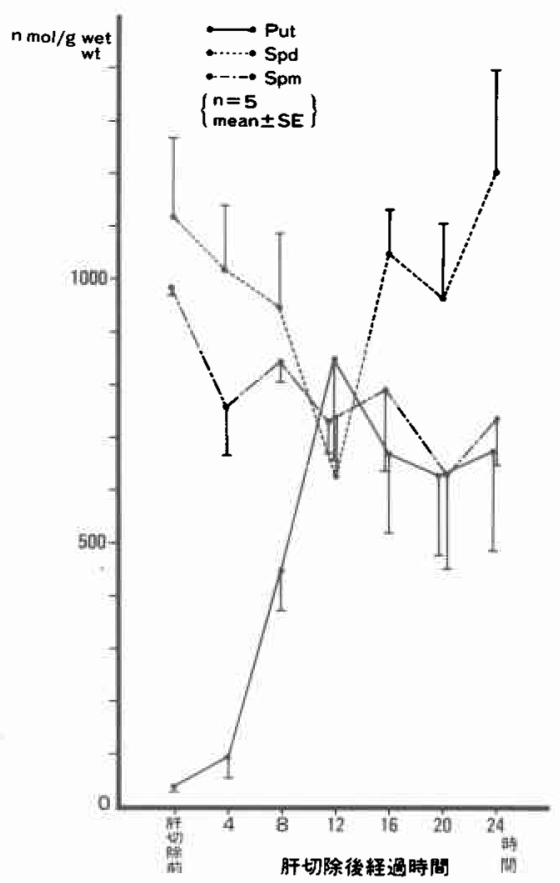

$\mathrm{nmol} \pm \mathrm{g}$ 湿重量となった。 Spdは12時間後まで漸減 し, 以後増加した（図16）.

(vi）減黄72時間肝切除群の組織ポリアミンの変化 Put は肝切除 12 時間後 $522 \pm 93 \mathrm{nmol} / \mathrm{g}$ 湿重量とピー ク值を示し, 以後24時間後には半減した。 Spd 8 時
図15 减黄 6 時間肝切除群の組織ポリアミン

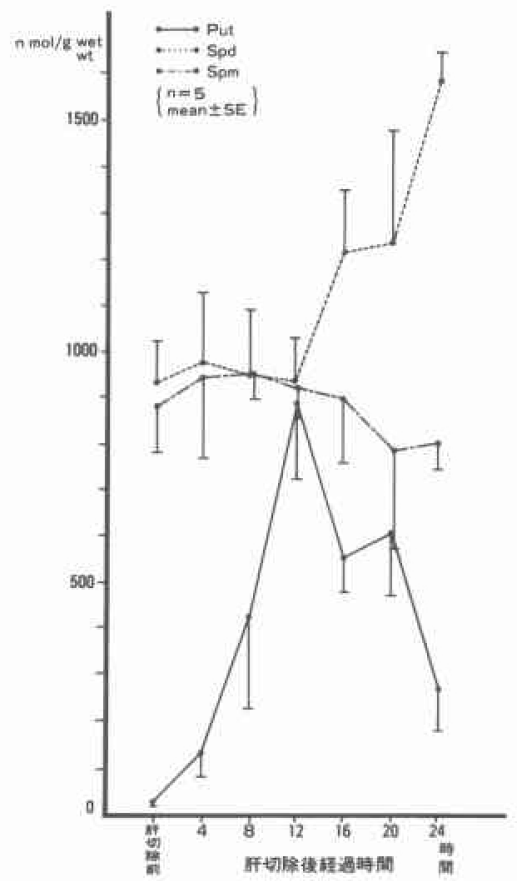

因16 减黄24時間肝切除群の組織ポリアミン

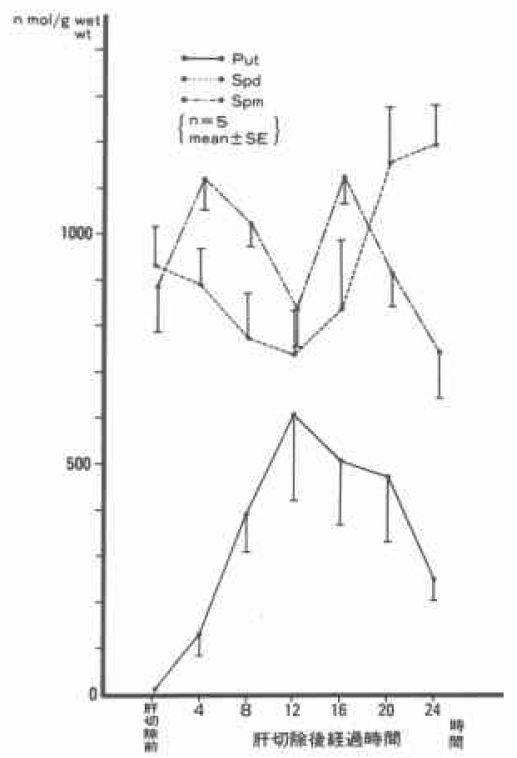

間まで漸减し，以後増加した（図17).

（vii）各肝切除群の Put の動態

肝切除後 4 時間から 8 時間までは, 各群に大きな差 は認められないが12時間後には, 黄疾肝切除群は正常 
図17 減黄72時間肝切除群の組織ポリアミン

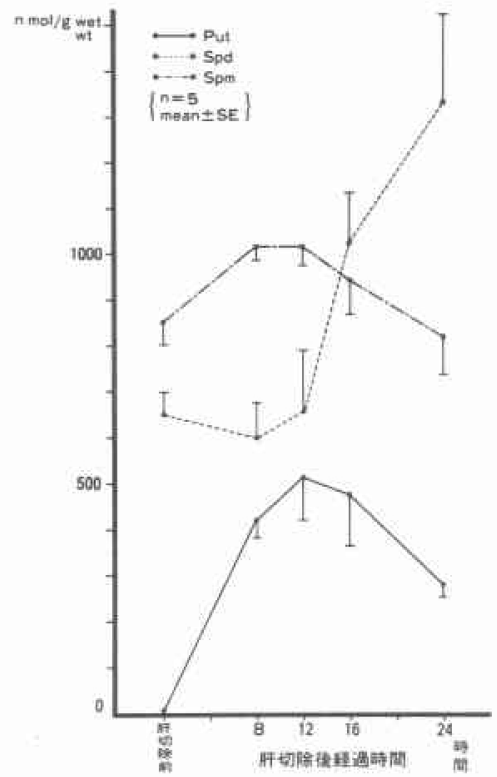

図18．各肝切除群のPut の動態

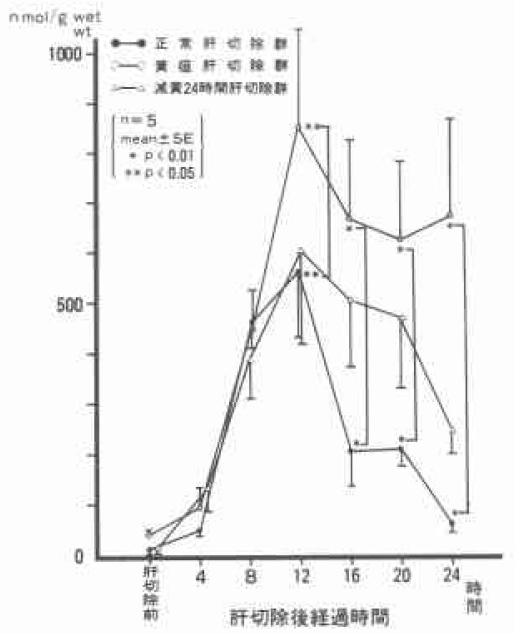

肝切除群に比ベピーク値が有意に高値を示し, 以後 24 時間をで有意の差をむって高値を持続した，正常肝切 除群は12時間以後は著明な減少傾向が認められた。減 黄24時間肝切除群のピーク値は正常肝切除群と大差な いが24時間までの減少はゆるやかであった（図18）。

（5）胆汁採取群

（i）正常肝切除群および対照群の血清, 胆汁, 尿ポリ アミンの変化

正常肝切除群の術後12時間で採取した血清, 胆汁,
表 2 血清, 胆汁中, 尿中ポリアミンの比較

\begin{tabular}{|c|c|c|c|c|}
\hline & & & & $\left(\begin{array}{l}n=6 \\
\text { mean } \pm S E \\
n \text { moi } / m \ell\end{array}\right)$ \\
\hline & & Put & Spd & Spm \\
\hline 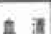 & 五畐䎲 & $1.6 \pm 0.5$ & $2.4 \pm 0.8$ & $0.5 \pm 0.2$ \\
\hline Ex in & 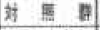 & $1.6 \pm 0.6$ & $1.8 \pm 0.6$ & $0.3 \pm 0.1$ \\
\hline & 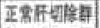 & $0.8 \pm 0.2$ & $1.0 \pm 0.4$ & $0.4 \pm 0.2$ \\
\hline 䣬 & 蛅 㫷 & $1.0 \pm 0.5$ & $0.7 \pm 0.2$ & $0.3 \pm 0.1$ \\
\hline & 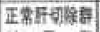 & $123 \pm 26$ & $129 \pm 45$ & $30 \pm 10$ \\
\hline 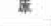 & 对 国 & $120 \pm 45$ & $108 \pm 25$ & $21 \pm 7$ \\
\hline
\end{tabular}

尿の Put 濃度は各 $1.6 \pm 0.5 \mathrm{nmol} / \mathrm{ml} ， 0.8 \pm 0.2 \mathrm{nmol} /$ $\mathrm{ml}, 123 \pm 26 \mathrm{nmol} / \mathrm{ml}$ であった．胆汁 Put 濃度は血清 の約 $1 / 2$, 尿の約 $1 / 150$ の濃度であった，血清，胆汁，尿 の Spd 濃度は各 $2.4 \pm 0.8 \mathrm{nmol} / \mathrm{ml}, 1.0 \pm 0.4 \mathrm{nmol} / \mathrm{ml}$, $129 \pm 45 \mathrm{nmol} / \mathrm{ml}$ であった。胆汁 Spd 濃度は血清の1/ 2 以下であり，尿の約 $1 / 120$ 濃度であった，血清, 胆 汁, 尿の $\mathrm{Spm}$ 濃度は各 $0.5 \pm 0.2 \mathrm{nmol} / \mathrm{ml} \quad 0.4 \pm 0.2$

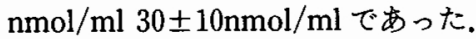

旰切除を負荷しない対照群の血清, 胆汁, 尿ポリア ミンは表 2 のごとく, 胆汁 Put, Spd 濃度は尿のそれの 1/100以下であった. 肝切除群と対照群との間では, 血 清, 胆汁，尿いずれも大きな差異を認めなかった。

\section{IV. 考 察}

Dykstra ${ }^{13)}$, Raina $5^{14)}$ により肝部分切除後早期よ り Put, Spd が増加することが報告されて以来, 正常 ラット肝部分切除後の再生肝を用いたポリアミンの研 究は数多く報告されている。 しかし黄疸障害肝はもと より減黄による障害軽減後の肝部分妡除再生肝の組織 ポリフミンの変化をみた報告はない，本実験で指標と して用いたポリアミンは生理活性アミンであり，1級 又は 2 級了ミ八基を 2 個以上有する直鎖の脂肪族炭化 水素化合物である。ポリアミンの中の Put, Spd, Spm, $\mathrm{Cad}$ の 4 つのポリアミンが生体では，流とんどを占め ている、最近その働きとして細胞増殖の関与，DNA， RNA 蛋白合成との関連, 種々の䣼素活性の調節など と関係していることがわかってきた。

本実験で正常ラット肝部分切除後, 再生肝の組織 Put 量は12時間後にピーク値を示し, 以後急速に減少 した. 組織 Spd 量はやや遅れて 3 日後にピーク值を示 し以後减少した. Put の経時的変化は血清 GOT, GPT のそれとよく相応し，Spdの経時的变化は組織 RNA 量のそれとよく相応していた. Raina ら ${ }^{14)}$ も再生肝に おいて組織 Spd 量が組織 RNA 量とよく相関するこ とより, Spd が RNA 合成の調節因子として働いてい ると述べている. 
胆管閉塞により，血清総ビリルビン值は 1 週間後に ピークを示すが以後減少した. Miyata ${ }^{15)}$ の成績も同様 であり閉塞期間と血清総ビリルビン値とは相関しない と考克られた。

組織 Put 量は胆管閉塞12時間後著明に増加し正常 の約50倍のピークに達した。 24時間後には著明に減少 したが 4 週間後も 5 倍の高値を持続していた。この組 織 Put の経時的変化は血清 GOT, GPT のそれとよく 類似していた. また Spd は 3 日後, Spmは 1 週間後 ピークを示した.この黄疸群の組織 Put, Spd の経時的 変化のパターンは正常肝切除群のそれとよく類似して おり，黄百による障害肝でも肝部分切除後の再生肝々 同様の修復機序が働いているものと考えられた。しか し正常肝切除群は14日後には肝重量がもとにもどりは ぼ再生が完了したと思われる時点で組織 Put は正常 に復したが，黄㾝群では胆管閉塞による障害が続く間 高値を持続していた。

減黄群に括ける血清総ビリルビン值は，1週間胆管 閉塞後, 减黄72時間でほぼ正常値に復した。このこと より本実験モデルが減黄効果にすぐれたよい方法であ ると考兄られた。組織 Put, Spd 量は减黄時間とともに 減少し, 72時間後にはほぼ正常值に復した。血清 GOT, GPT が胆管閉塞解除後経時的に肝機能の改善に伴 なって低下するのとよく類似していた。

黄㾝肝切除群は肝部分切除後 24 時間で注注 $40 \%, 48$ 時間後では，ほぼ全例死亡することより，残存肝の予 備力はなく肝障害も極めて重篤であると考学られた。 もっとも肝障害の強い黄疸肝切除群の血清 GOT, GPT は, 正常肝切除群がピークを示す12時間後にもあ まり增加しなかった。減黄肝切除群の血清 GOT, GPT は12時間後にピークを示し減黄が十分な程ピーク值は 正常肝切除群に近づいて増加した。このことは肝細胞 の障害が高度な肝硬変 ${ }^{16)}$, 肝性昏睡時には肝細胞は疲 幣し，むしろこれらの酵素の逸脱は少なくなるのと同 様の変化と考兄られた。組織 Put 量は肝障害がもっと も強い黄㾝肝切除群のピーク值がもっとも高かった。 また黄疸肝切除群の Put 量は正常肝切除群に比べ有 意差をもって高値を持続した, 減黄24時間肝切除群で は, 黄疾肝切除群に比ベピーク值の低下とゆるやかな 減少を示し正常肝切除群の Put のパターンに近つい たが24時間後の值は，な拈高值であった。以上より肝 切除後再生肝の Put 動態は残存肝の障害の程度に応 じた特徵的なパターンを示した。

黄㾝群, 黄疸肝切除群の組織 Put の著明な増加の原
因は, 胆汁採取群の結果より Put, Spd の胆汁への排泄 が尿に比べてはるかに少なく，また胆管閉塞期間が長 くなっても増加しないことより胆管閉塞による胆汁 らっ滞由来のものではないと考学られた。また胆管閉 塞による胆管上皮の増生による影響も考えられた。し かし胆管上皮の増生は閉塞 4 週以後に, 著明になると

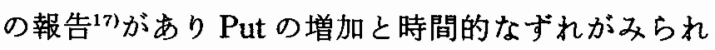
たことより, 黄疸群, 黄㾝肝切除群の Put の増加は肝 細胞由来の組織 Put の増加と考えられた.

この Put の増加には $2 つ の$ 経路が考えられる．1つ はオルニチンデカルボキシラーゼ（以下 ODC）による オルニチンから Putへの経路である. 従来より肝部分 切除 ${ }^{18)}$ 扩よび肝障害をひき技こす薬物 ${ }^{19)}$ の投与により ODC が増加すると云われている. 胆管閉塞により Put が著明に増加することより閉塞性黄疸は ODC 活性上 昇因子と考兄られた，最近明らかにされてきたもら 1 つの経路はSpd から Putへの経路である. 本実験にお いて黄疸群, 各肝切除群で術後12時間までの早い時期 に組織 Put 量は急速に増加し, 反対に組織 Spd 量は時 を同じくして急速な减少を示したことより Spdから Putへの低位のポリフミン生成の可能性が考えられ た. Siimes ${ }^{20)}$ はラット肝部分切除後の再生肝で, $\mathrm{Hölltä{ } ^ { 1 9 9 }}$ はラット腹腔内に $\mathrm{CCl}_{4}$ を投与した障害肝で 早期に Spdょり Put への生成が促進することを認め ている. Pegg ${ }^{21}$, Matsui ら ${ }^{221}$ は生成経路としてSpd よ

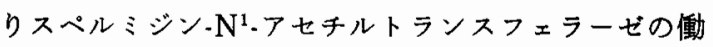
きにより $\mathrm{N}^{1}$ ・アセチルスペルミジンがつくられ，さら にポリアミンオキシダーゼの働さでPut が生成され ると説明している。

黄㾝肝切除群のごとき障害が高度になると組織 Put が増加することは興味のあるところである．肝部切除 後の再生肝では, 細胞周期でいら DNA 合成前の $\mathrm{G}_{1}$ 期 に種々の酵素活性 ${ }^{23)}$ が認められる. 肝切除 $3 \sim 4$ 時間 後には, Put 合成の律速酲素である ODC が増加し, 22 時間後にはチミジンキナーゼ活性が増加し，24時間後 には ${ }^{3} \mathrm{H}$-チミシシンの DNA への取り込みが増加してく ると報告されている。ODC 阻害剤2425)を用いた Put 合 成の阻害が DNA 合成をも阻害することにより Put が DNA 合成に必要であるとの報告は多いが，また反 対に DNA 合成を伴なわないPut 合成の増加の報告 ${ }^{26)}$ もあり put 合成と DNA 合成との関係はまだ十分解明 されていない.向山27》は同じ実験系を用いで $\mathrm{H}$-チミジ ンを投与し，DNA 合成をラジオオートグラフィーで 検索し, ${ }^{3} \mathrm{H}$ ・ミシシン取り込み細胞の比率を示した。 
づれの群も DNA 合成ピークは肝切除24時間後にみら れ，黄疸肝切除群ではほとんど3 $\mathrm{H}$-チミジンの取り込 みはみられず, 減黄時間に比例してDNA 合成も増加 してくると報告している. 黄疸にさらに肝切除が加わ るような障害肝の肝再生では, DNA 合成が強く障害 されるが，Putの生合成はえ進していることょり， $\mathrm{G}_{1}$ 期の種々の反応の中で Put 合成の増加は DNA 合成 の増加には結びつかなかった，むしろ Put の高値の持 続は肝再生が不良であると考えられる結果を得た.

一方, 肝部分切除以外に $\mathrm{CCl}_{4}{ }^{19}$, チオアセトアシ ド28)など種々の肝毒性の薬物による障害肝で ODC 活 性が増加し Put が増加する報告は多い. 同様に黒川胳， Milano ら $^{30}$ はラットへの発癌剂投与に上り投与直後 より肝組織 Put の持続的な増加を認めている。他の葴 器の障害でも同様の変化が認められる. Selmeci ${ }^{311}$ は ラット片側の尿管結禁により結紮側の腎組織 Put の 著明な増加を, Ekström ${ }^{32}$ はラット䅡下腺, 舌下腺の導 管を結禁し結禁側の腺組織 Put の増加を報告してい る. Daikuhara ${ }^{33)}$ は D-ガラクトサミン投与による実験 的肝炎をつくり, 障害のもっとも強い時期に ODC, Put が増加し血清 GOT, GPT の変化とよく相関した と報告している。本実験でる, 黄㾝群, 正常肝切除群 の組織 Put の動態は血清 GOT, GPT による肝障害の 程度と密接に関係していると思われた。 しかし黄疸肝 切除群のごとき肝障害が高度な場合, 血清 GOT, GPT はあまり増加せず肝障害の程度の指標にならなかっ た。しかし組織 Put 量は肝障害が高度な場合は高値を 示し, 減黄により障害が取り除かれると低下すること より肝障害の程度に応じて変化して蛙り, 肝障害の程 度を知る上で指標になると考えられた．Desser ${ }^{34)}$ は肝 不全の患者の血浆 Put が増加することを報告した．こ れは肝組織内の Put が血浆に反映されていると考克 られ，臨床的にも肝障害と血浆 Put とが相関している と考えられた。

Daikuhara $^{33)}$ は Put 投与によりD-ガラクトサミンに よる肝炎の障害が病理学的, 生化学的に改善したこと より, Put が肝障害治瘾過程に重要な働きをしている と述べている。これらを考台わせると, 肝障害時の 組織 Put の増加は肝障害の程度の指標であるととも に, 肝障害を軽減しようとする合目的な代償的保護因 子としての働きを持つ可能性が示唆された。

\section{V. 結 語}

呑竜ラットに黄百群, 减黄群, 正常肝切除群, 黄疸 肝切除群, 減黄肝切除群を作製しそれぞれにおける組
織ポリアミンと血清 GOT, GPT の動態を比較検討し た.

（1）胆汁中の Put, Spd 濃度は尿中に比べ極めて低 かった。 その主な排泄経路は尿路によると考学られた。

(2) 胆管閉塞により肝組織 Put 量は12時間後著明 に増加し, 閉塞による肝障害が続く間高檤を持続した。 組織 Put の変化は血清 GOT, GPT の変化とよく相応 した.

（3）减黄により肝障害が取り除かれると, 肝組織,

Put, Spd 量は減少し, 血清 GOT, GPT の変化とょく 相応した.

（4）黄疸肝切除群のごとき肝障害が重篤な時の再生 肝では, Put は増加し, 减黄肝切除群のごとき肝障害が 軽減された後の再生肝ではPutは減少した。

（5）以上の結果から組織 Put は肝障害の程度と比 例した增減を示し, 障害の程度の指標になると考えら れた。また障害に対する代償的保護因子の働きを持つ 可能性が示唆された。

稿を終るにあたり，御指導と御校閲を賜りました本学第 1 外科学教室塩野谷恵彦教授に深甚なる感謝の意を表しま す。また終始御指導をいただいた松本隆利先生, 二村雄次講 師, 浜松医科大学法医学教室鉿木修助教授, 本学第 1 生化学 教室永津俊治教授に深く感謝の意を表します。 あわせて御 協力, 御援助をいただいた腫韵研究室の諸先生方に厚くお 礼申し上げます。

な祅本稿の要旨は第21回日本消化器外科学会総会 (1983 年 2 月名古屋), 第22回日本消化器外科学会総会 (1983年 6 月奈良), 第70回, 日本消化器病学会総会(1984年 3 月東京), Polyamine: Basic and Clinical Aspects, A Satellite Symposium of the 3rd International Congress on Cell Biology (1984 August Gifu)において発表した。

\section{文 献}

1) Kaplan AA, Traitz JJ, Mitchel SD et al: Percutaneous transhepatic cholangiography. Ann Inter Med $54: 856-869,1961$

2）高田忠敬：影像下直達法による経皮的胆管ドレ ナージの研究. 日消外会誌 $9: 791-803,1976$

3）二村雄次, 早川直和, 弥政洋太郎：経皮経肝胆道内 視鏡。胃之腸 $16: 681-689 ， 1981$

4) Higgins GM, Anderson RM: Experimental pathology of the liver. Arch Pathol 12: 186-202, 1931

5) Fishback FC: A morphologic study of regeneration of the liver after partial removal. Arch Pathol 7 : 955-977, 1929

6) Michaëlson $M$ : Bilirubin determination in serum and urine. Studies on diazo methods and 
a new copper-azo pigment method. Scand J Clin Lab Invest $13: 1-80,1961$

7) LaDue JS, Wróblewski F, Karmen A: Serum glutamic oxaloacetic transaminase activity in human acute transmural myocardial infarction. Science $120: 497-499,1954$

8) Schmidt G, Thannhauser SJ : A method for the determination of desoxyribonucleic acid. ribonucleic acid and phosphoproteins in animal tissues. J Biol Chem 161 : 83-89, 1945

9) Schneider WC: Phosphorus compounds in animal tissues. J Biol Chem $161: 293-303,1945$

10) Matsumoto T, Suzuki O, Nimura $Y$ : A fluorometric assay for total diamines in human urine using human placental diamine oxidase. Clin Chim Acta $112: 141-148,1981$

11) Matsumoto $T$, Suzuki O, Nimura $Y$ : A new enzymatic assay for total diamines and polyamines in human urine of cancer patients. Cancer Res Clin Oncol $100: 73-84,1981$

12）藤田登美雄, 林 守正, 石田泰夫：高速液体ク口マ トグラフィーによるポリフミンの分析．島津評論 $38: 131-134,1981$

13) Dykstra WG, Herbst EJ : Spermidine in regnerating liver : Relation to rapid synthesis of ribonucleic acid. Science 149:428-429, 1965

14) Raina A, Jänne J, Siimes $M$ : Stimmulation of polyamine synthesis in relation to nucleic acids in regenerating rat liver. Biochim Biophys Acta $123: 197-201,1966$

15) Miyata K : Delayed recovery of mitochondrial function in rat liver after releasing biliary obstruction. Nagoya J Med Sci 45:97-105, 1983

16）鈴木 宏：GOT, GPT その数值をどう読むか. 日 臨 $34: 2444-2452,1976$

17）佐藤寿雄, 小山研二：閉塞性黄㾞の病態生理一肝 障害を中心として一. 外科 $36: 426-433,1974$

18) Hölttä E, Jänne J : Ornithine decarboxylase activity and the accumulation of putrescine at early stages of liver regeneration. FEBS Lett $23: 117-121,1972$

19) Hölttä E, Sinervirta $R$, jänne J : Synthesis and accumulatin of polyamines in rat liver generating after treatment with carbon tetrachloride. Biochem Biophys Res Commun $54: 350-357$, 1973

20) Siimes M : Studies on the metabolism of 1,4-Cspermidine and 1,4-C-spermine in the rat. Acta Physiol Scand Supple 298: 1-66, 1967

21) Pegg AE, Matsui I, Seely JE et al: Formation of putrescine in rat liver. Med Biol $59: 327$ $-333,1981$
22) Matsui I, Pegg AE: Increase in acetylation of spermidine in rat liver extracts brought about by treatment with carbon tetrachloride. Biochem Biophys Res Commun $92: 1009-1015$, 1980

23) Miura $Y$, Fukui N : Pleiotypic response of regenerating liver. Adv Enzyme Regul 14: 393-405, 1976

24) Kato $Y$, Nishihara $H$, Inoue $H$ et al : Polyamine metabolism and DNA synthesis in regenerating rat liver. J Biochem $84: 1617$ $-1623,1978$

25) Pösö H, Pegg AE: Effect of $\alpha$-difluoromethylornithine on polyamine and DNA synthesis in regenerating rat liver, reversal of inhibition of DNA synthesis by putrescine Biochimica et Biophysica Acta $696: 179-186,1982$

26) Schrock TR, Oakman NJ, Bucher NLR: Ornithine decarboxylase activity in relation to growth of rat liver. Biochim Biophys Acta $204: 564-577,1970$

27）向山憲男：肝再生に関する実験的研究一閉塞性黄 迫解除後の肝切除ラットについて一，日消外会誌 $14: 1427-1435,1981$

28) Matsui I, Pegg AE: Effect of thioacetamide, growth hormone or partial hepatectomy on spermidine acetylase activity of rat liver cytsol. Biochim Biophys Acta 633:87-94, 1980

29）黑川善栄：3'-methyl-4-dimethylaminoazobenzene 投与によるラット肝癌形成過程における肝 組織および尿ポリアミンの動熊. 名古屋医学 $106: 189-196,1984$

30) Milano G, Aussel C, Stora $C$ et al: Intrahepatic polyamine levels during rat liver carcinogenesis induced by $\mathrm{N}$-2-fluorenylacetamide. Carcinogenesis 2 : 109-113, 1981

31) Selmeci L, Pósch E, Mosonyi J et al : Effect of unilateral ureteral obstruction on renal polyamine levels in rats. Experientia $37: 24$ $-25,1981$

32) Ekström J, Rosengren E: Changes in diamine and polyamine metabolism in the duct-ligated submaxillary and sublingual glands of the rat. Acta Physicol Scand 119 : 287-292, 1983

33) Daikuhara Y, Tamada F, Takigawa $\mathrm{M}$ et al : Changes in polyamine metabolism of rat liver after administration of D-galactosamine. Gastroenterology $77: 123-132,1979$

34) Desser H, Kleinberger G, Kläring J : Plasma polyamine levels in patients with liver insufficiency. J Clin Chem Clin Biochem 19: 159-164, 1981 